\title{
二相域制御圧延材の延性不安定破壊に関する研究
}

安藤 柱 ${ }^{*}$ 最上 和 生 $^{* *}$ 藤 林 伸 平***
松下 雄 $* * *$ 小 倉 信 和**

\section{On the Ductile Unstable Failure of Steel Control-Rolled in Two Phase Regions}

by

\section{Kotoji Andō*, Kazunari Mogami**, Shinpei FujibaYashi***, Hisao Matsushita**** and Nobukazu OGURA**}

Ductile unstable failure test has been made on the high strength control-rolled steel over a wide temperature range. The effects of separation, compliance of the loading system and also temperature on the ductile unstable failure features have been investigated in detail by using compact specimens. The test results were mainly analysed with respect to material and applied tearing moduli. The main conclusions are as follows.

(1) Stable-unstable behavior is in good agreement with theoretical prediction except that material tearing modulus at instability is larger than 300.

(2) Even at the low temperature range where separation is notable, the specimen showed high resistance to tearing instability.

(3) Separation which initiated before the maximum load point, did not induce brittle fracture and also tearing instability. On the contrary, it prevents the initiation of brittle fracture by decreasing the plastic constraint.

キー・ワード：J 積分, 破壊じん性, 制御圧延材, 延性不安定破壊, セパレーション

\section{1 緒言}

二相域圧延された制御圧延材では, 集合組織の発達 により，圧延面に平行な層状割れすなわちセパレーシ ョンが発生することがある。このセパレーションが発 生すれば，き裂先端部の塑性拘束が緩和されるために， 二相域圧延材は極めて優れたぜい性破壊発生特性とぜ い性き裂伝ぱ阻止性能を示すことが知られている。乙 かし，とれらはいずれも低コンプライアンスな荷重系 に郝兴試験結果であり，高コンプライアンスな荷重 系での破壊特性に関しては, 一, 二の先進的研究は山 るものの，未だ研究例は少なく不明の点が多い。すな わち，セパレーションの発生により，Fig. 3 のような pop-in 状の荷重低下が生じるが，高コンプライアン スな荷重系に蛙いては，これにより動的効果が生じて， ぜい性破壞や延性不安定破壊が誘起される可能性はあ るのか否か，西るいはまた，セパレーションが多数発 生した場合にはき裂先端部は完全な平面応力状態とな るが，この場合薄板材に類似した低エネルギ引裂破壞
が発生する可能性はあるのか否か，等に関しては必ず しも十分な検討がなされていないと言光る。

そこで本論文においては，それらに関する知見を得 る目的で，二相域圧延された制御圧延材から切り出さ れたCT 試験片を用いて, 高コンプライアンスな荷重 系に拈ける破壊特性の温度とコンプライアンス依存性 を検討した結果を報告する。

\section{2 供試材と実験方法}

供試材は，前報と同一の二相域圧延された板厚 23 $\mathrm{mm}$ の 50 キロ級高張力鋼である. その化学成分と機械 的性質をとれぞれ Table I と Table II に示す. 試験 片は, Fig. 1 のように, 板厚 $B$ を 23.8 および $4 \mathrm{~mm}$ の 3 通りに变えたITCT 型であり, 供試鋼板からL下方向に採取した。 また疲労予き裂導入時の最大応力 拡大俰数 $K_{f \max }$ は $80 \mathrm{kgf} / \mathrm{mm}^{3 / 2}$ 以下でかつ下式を 満足するょうにした.

$$
K_{f \max }<0.6 K^{*}\left(\sigma_{y 1} / \sigma_{y 2}\right)
$$

ここで，K* はへさ開破壞あるいは最初にセパレーシ

$\dagger \quad$ 原稿受理 昭和60年12月16日 Recieved Dec. 16, 1985

* 正会員 横浜国立大学工学部 横浜市保土ケ谷区常盤台, Faculty of Engineering, Yokohama National University, Tokiwadai, Hodogaya-ku Yokohama

** 横浜国立大学工学部 横浜市保土ケ谷区常盤台, Faculty of Engineering, Yokohama National University, Tokiwadai, Hodogaya-ku, Yokohama

*** 横浜国立大学大学院 (現, 出光エンジニアリング(株)) 横浜市保土ケ谷区常盤台, Graduate Student, Yokohama National University, Tokiwadai, Hodogaya-ku, Yokohama

**** 三井造船(株) 市原市八幡海岸通, Mitsui Engineering and Shipbuilding, Co., Ltd, Yahatadori, Ichihara 
Table I. Chemical composition of the material tested.

\begin{tabular}{c|c|c|c|c}
\hline $\mathrm{C}$ & $\mathrm{Si}$ & $\mathrm{Mn}$ & $\mathrm{P}$ & $\mathrm{S}$ \\
\hline 0.09 & 0.36 & 1.46 & 0.018 & 0.005 \\
\hline
\end{tabular}

Table II. Mechanical properties of the material tested $\left(-40^{\circ} \mathrm{C}\right)$.

\begin{tabular}{c|c|c|c}
\hline $\begin{array}{c}\text { Yield stress } \\
\left(\mathrm{kgf} / \mathrm{mm}^{2}\right)\end{array}$ & $\begin{array}{c}\text { Tensile } \\
\text { strength } \\
\left(\mathrm{kgf} / \mathrm{mm}^{2}\right)\end{array}$ & $\begin{array}{c}\text { Elongation } \\
(\%)\end{array}$ & $\begin{array}{c}\text { Reduction } \\
\text { of area } \\
(\%)\end{array}$ \\
\hline 48.0 & 55.9 & 32 & 74 \\
\hline
\end{tabular}

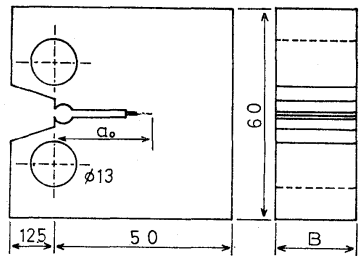

Fig. 1. CT specimen.

ョンが発生するときの応力拡大係数である。また $\sigma_{y 1}$ および $\sigma_{y 2}$ はそれぞれ疲労予き裂導入時拉よび試験時 に和ける降伏応力である。

試験には系のコンプライアンスを増大させるために， Fig. 2 に示す高コンプライアンス発生装置を用いた. 本装置では，ばね定数が $40 \sim 200 \mathrm{kgf} / \mathrm{mm}$ のコイル ばねを装着して, 単調増加荷重はもちろんのこと, 様 様な変動荷重下に打ける試験も実施することができる. 今回実施した試験は, 剛な試験系での $J-R$ 曲線 の評 価とばねを介した高コンプライアンスな系での延性不 安定破壤の 2 種類である. 試験時のクロスヘッド変位 速度は, $J-R$ 曲線の評価試験では $2 \mathrm{~mm} / \mathrm{min}$, 延性 不安定破壊試験では $20 \mathrm{~mm} / \mathrm{min}$ とした。 その他の試 験の変位速度は前報に示した通りである.

J 積分と安定延性き裂進展量の評価は ASTM 規格

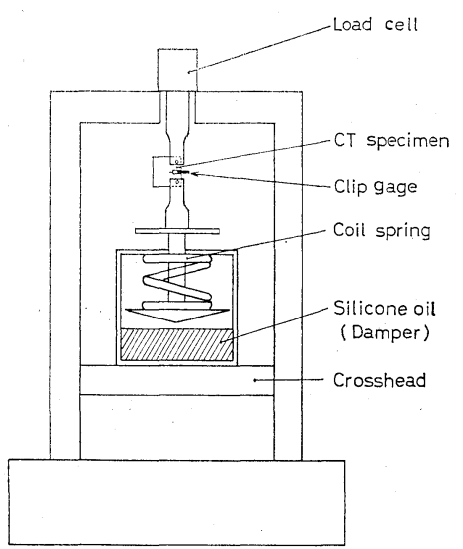

Fig. 2. Test equipment with coil spring.
E813 に従った. 一方, き裂成長による丁積分の補正 には，筆者らが以前より使用している方法を用いたが， その結果は ASTM 規格E 813 によるものと同一であ る.

\section{$3 \mathrm{~J}$ 積分に基づく延性不安定破壞理論}

Paris らの延性不安定破壊理論によれば, 不安定破 壊条件は次のように与兄らる。

$$
T_{\text {app }} \geqq T_{\text {mat }}
$$

ここで， $T_{\mathrm{app}}$ 拉よび $T_{\mathrm{mat}}$ はとれぞれ延性破壊荷重 係数祘上び延性破壊材料係数で离り, 次の上うに与兄 られる無次元量である.

$$
\begin{aligned}
& T_{\text {app }}=\frac{E}{\sigma_{f}{ }^{2}}\left(\frac{d J}{d a}\right)_{\Delta_{T}} \\
& T_{\text {mat }}=\frac{E}{\sigma_{f}{ }^{2}}\left(\frac{d J}{d a}\right) .
\end{aligned}
$$

ここで，Eはヤング率， $\sigma_{f}$ は流動応力， $\Delta_{T}$ は試験系 全体でみたときの荷重点变位である。一般線な構造物 に対して $T_{\text {app }}$ を求めることは現在のところ必ずしも 容易ではないが, Fig. 2 のような単純な荷重系の場合 には, Ernst ら゙をより次のように与兄られている.

$$
\begin{aligned}
T_{\mathrm{app}}= & \frac{E}{\sigma_{f}^{2}}\left[-r \frac{J}{b}\right. \\
& +\frac{\eta^{2} P}{b^{2}} \frac{\left.K_{M}+\frac{1}{P} \frac{d P}{d \delta}+\frac{\eta^{2} P}{b^{2}}\left(\frac{1}{\frac{\sigma_{f}^{2}}{E} T_{\mathrm{mat}}+r \frac{J}{b}}\right)\right\}}{}
\end{aligned}
$$

ここで, $\quad \gamma=1+0.76(b / W), \quad \eta=2+0.522(b / W), \quad b$ はリガメント長さ， $W$ は板幅， $P$ は試験片単位厚さあ たりの荷重, $\delta$ は試験片の荷重線変位である。また $K_{M}$ は試験片単位板厚あたりの試験系のばね定数であ り，ここではばね係数と称することにする.

ところで, 式(2)に式(5)を代入すれば，不安定化条件 式は下式の上うになる.

$$
K_{M} \leqq-d P / d \delta
$$

これより， $K_{M}=0$ すなわちコンプライアンスが 無限 に大きいときには，最大荷重点に肳いて不安定化する ことになる。 これより, 延性不安定破壊発生時の J 積 分 $\left(J_{\text {inst }}\right)$ の下限值は最大荷重時の $\mathrm{J}$ 積分 $\left(J_{p \cdot \max }\right)$ であると言觉る。

\section{4 実験結果とその考察}

\section{$4 \cdot 1 \boldsymbol{J}-\boldsymbol{R}$ 曲線の評価}

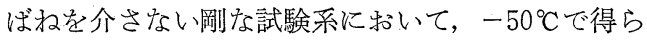
孔た荷重一变位曲線の一例を Fig. 3 亿示す. 板厚 $B$ が $23 \mathrm{~mm}$ の場合にはセパレーションの発生に伴い, ポ ップイン状の荷重低下が生じている. これに対して, $B=8 \mathrm{~mm}$ の薄板材の場合には, 滑らかな荷重一変位曲 線であり，セパレーションの発生に伴う荷重低下はほ とんど認められない。このように, 試験片板厚の差に 


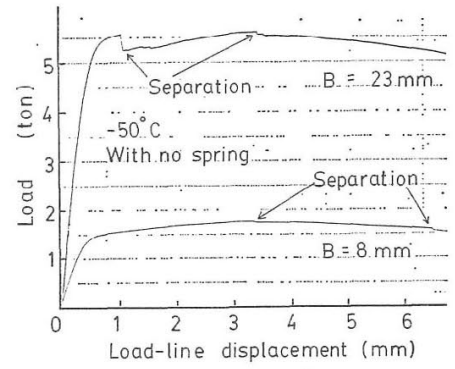

Fig. 3. Load versus load-line displacement of specimen.

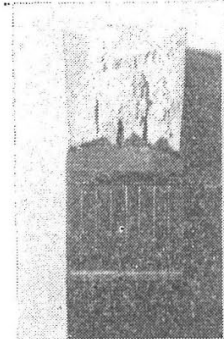

(a) $\Delta a=1.2 \mathrm{~mm}$

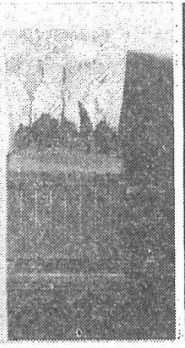

(b) $\Delta a=4.5 \mathrm{~mm}$

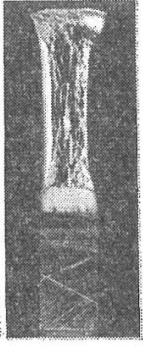

(c)

\section{$\mathrm{J}=117 \mathrm{kgf} / \mathrm{mm} \quad \mathrm{J}=205 \mathrm{~kg} f / \mathrm{mm}$}

Fig. 4. Macroscopic photograph of failure surface. $\left(-50^{\circ} \mathrm{C}\right)$

よって，荷重一変位曲線の形状に大きな差を生じた原 因としては，薄板材でほほぼ平面応力状態であるため そセパレーションが発生して歹塑性拘束が汪とんぞ低 下しないことと，さらにセパレーションそのものが Fig. 4 (c)のよらに微細であることによるものと考えら れる。

セパレーションの状況とその板厚低存性を Fig. 4

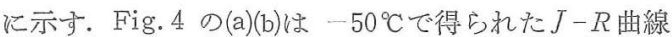
評価用試験片の破面であり，除荷後 $250{ }^{\circ} \mathrm{C}$ で加熱着色 してから液体空素中でへき開破塙させたものである。 破面には数本の大きなセパレーションが形成されて和 り，その間で延性き裂が若干のタンネリングを示して いる。延性き裂成長量 $\Delta a$ の評価には，ASTM 規格 E813の方法を用いたが，セパレーションと延性き裂 では，き裂進展の面が異なるために，七パレーション 部分はき裂長さに算定しないこととした。

ー $50^{\circ} \mathrm{C}$ で得られた $J-R$ 曲線とさ裂成長の效果学補 正した修正 $J-R$ 曲線走Fig. 5 に示寸。杂た，この修 正 $J-R$ 曲線から式(2)を用いて得られた延性破壞材料 係数 $T_{\text {mat }}$ 之J 積分との関係を $\mathrm{Fig} .7,8$ に示す. $T_{\text {mat }}$ はJ積分が増大するにつれてほぼ直線的に低下 する傾向学示している。

\section{$4 \cdot 2$ 延性不安定破壞特性}

高コンプライアンスな試験系での荷重ークロスヘッ

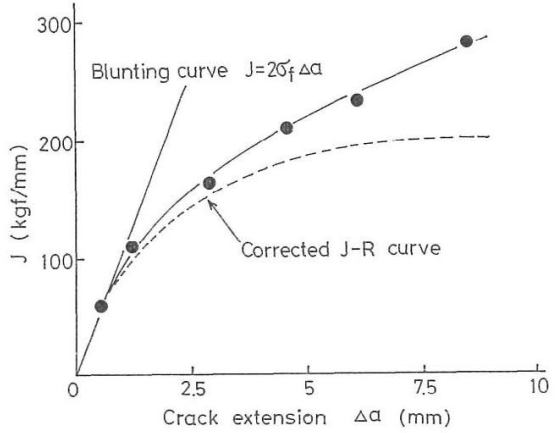

Fig. 5. J-resistance curve.

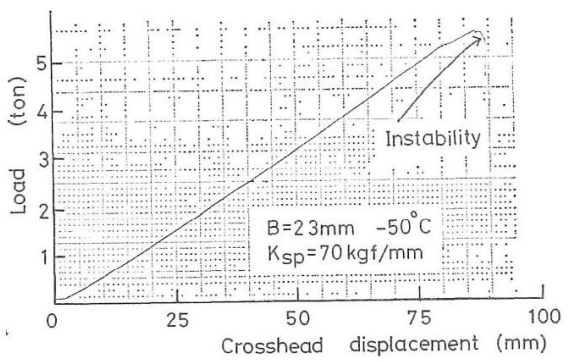

(a) Load versus crosshead displacement.

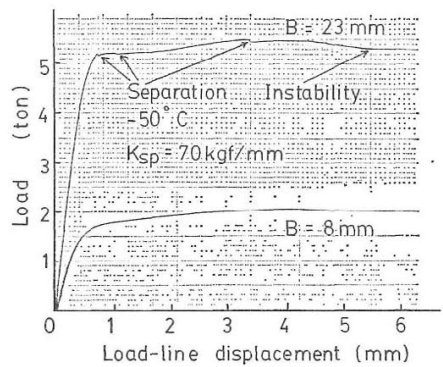

(b) Load versus load-1ine displacement of specimen.

Fig. 6. Load versus displacement diagram under the condition of high compliance.

ド変位曲線招よび試験片の荷重一变位曲線をFig.6 に 示す。図中には，不安定破壞発生点およびセパレーシ ョン発生点を气れぞれ矢印で示す。高コンプライアン スな試験系の場合には，セパレーションが発生して子， Fig. 3 のように顕著な荷重低下は生じないが，独特の 金属音と荷重一変位曲線に現机る微少な变化により, セパレーション発生点を同定することは容易であった。 Fig. 6 の場合には，延性不安定破偯以前に約 3 本の大 きなセパレーションが発生しているが，いずれる不安 定化点よりるかなり手前である。これるり，最大荷重 点以前に発生したセパレーション㥀接延性不安定破 壊を誘起していないと言光るが，これに関しては後で 詳細に検討することとする。

J積分に対する $T_{\text {mat }}$ と $T_{\text {app }}$ の変化状況を Fig. 7

と Fig. 8 に示すす. Fig.7 の黒如りの記号（）は， 


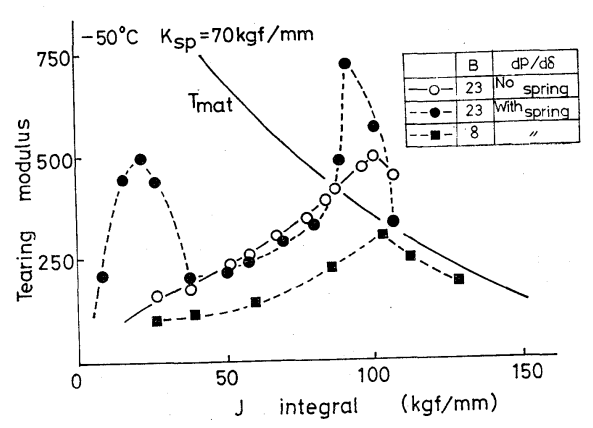

Fig. 7. Material and applied tearing modulus versus J-integral.

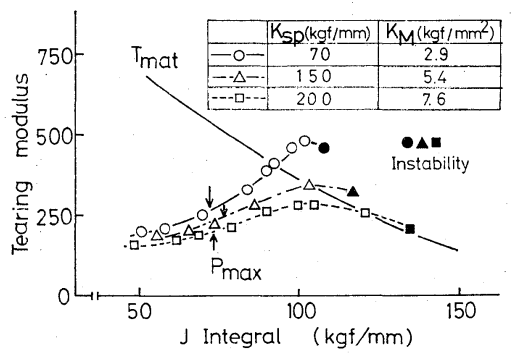

Fig. 8. Effect of spring constant on the applied tearing modulus versus J-integral curve.

ばねを介したときの $d P / d \delta$ を用いて $T_{\mathrm{app}}$ を算定し た結果である. $B=8 \mathrm{~mm}$ の場合には, 前述のごとく, セパレーションが発生しても荷重一変位曲線はなめら かであるために， $T_{\mathrm{app}}$ の変化傾向もなめらかである. これに対して，B=23 $\mathrm{mm}$ の場合には，セパレーショ ン発生時に和故る $d P / d \delta$ の特異な傾向を反映して, $T_{\text {app }}$ はセパレーション発生直後に急増し，その後低 下する傾向を示している。しかし，このようにして評 価された $T_{\mathrm{app}}$ が，J=90 $\mathrm{kgf} / \mathrm{mm}$ 付近で $T_{\mathrm{mat}}$ をは るかに越えているにもかかわらず不安定化していない ことから，この評価方法には問題があるものと考えら れる、そこで，ばねを介さない試験系に称いて，初期 き裂長さ $a_{0}$ が等しい別の試験片から得られた $d P / d \delta$ を用いて評価された $T_{\mathrm{app}}$ を○印で示す。 この場合に は, $T_{\mathrm{app}}$ はJ積分の增大につれてゆるやかに增大し， $T_{\text {app }}>T_{\text {mat }}$ となってしばらくしてから不安定化して 扣り，この $T_{\mathrm{app}}$ 評価方法は妥当なるのであると考兑 られる，そこで，以後はこの方法で $T_{\mathrm{app}}$ を評価する こととした.

$T_{\text {app }}$ の変化傾向に及ぼすコンプライアンスの影響 をFig. 8 に示寸． $T_{\mathrm{app}}$ は最大荷重時の J 積分を越兄 て変形が若干進行してから極大值を示し, その極大值 は系のばね俰数が増大するにつれて低下する傾向を示 している. 特に $K_{\mathrm{sp}}=200 \mathrm{kgf} / \mathrm{mm}$ の場合には, $T_{\mathrm{app}}$ が極大値を示した後 $T_{\mathrm{mat}}$ に沿って低下する傾向を示
している.この $T_{\mathrm{app}}$ の変化傾向は本供試材に固有の ものではなく, 原子炉圧力容器用 (A508 cl.3) 鋼に も共通したものである. な抢，この $T_{\text {app }}$ の変化傾向 とそれに付随して現れる Paris 理論適用上の問題点 については文献9)に詳しいのでここでは触れないこと とする.

本供試材ならびに 2 種類の60キロ級調質低合 $\left.{ }^{8}\right) 10$ 得られた延性不安定破壊発生時の $T_{\mathrm{app}}$ と $T_{\mathrm{mat}}$ の相 関をFig. 9 亿示高。同図より，不安定破壊時の $T_{\text {app }}$ が約 300 以下の場合には， $T_{\text {app }} \fallingdotseq T_{\text {mat }}$ がほぼ成立し ているが，そ机以上の $T_{\mathrm{app}}$ 領域では，不安定化時の $T_{\text {app }} T_{\text {mat }}$ に比べてかなり大き目の值を示している. このことから， $T_{\text {app }}$ が 300 以上となるような高コン プライアンスな荷重系に打ける不安定化条件式の妥当 性に関してはさらに検討する必要があると言える。

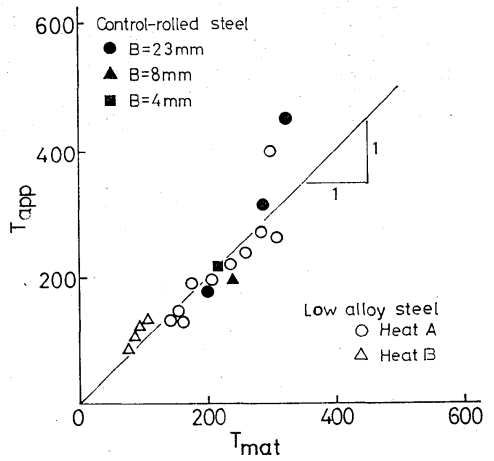

Fig. 9. The correlation between $T_{\text {app }}$ and $T_{\text {mat }}$ at instability point.

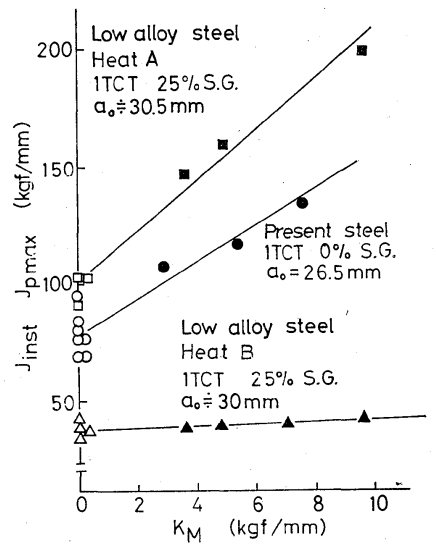

Fig. 10. Effect of spring coefficient of loading system upon $J$ inst

本供試材叔よび 2 種類の低合金鋼で得られた延性不 安定破壞発生時の $\mathrm{J}$ 積分 $\left(J_{\mathrm{inst}}\right)$ と試験亲のばね系数

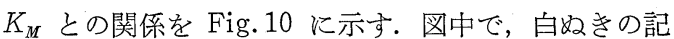
号は最大荷重時の $\mathrm{J}$ 積分 $\left(J_{p} \cdot \max \right)$ であり, 黒妨りの 記号は $J_{\text {inst }}$ である．前述のごとく， $J_{p \cdot \max }$ は $J_{\text {inst }}$ 
の下限值に相当するために，両者を併せて整理すれば，

$$
J_{\text {inst }}=J_{p \cdot \max }+C K_{M}
$$

と示せることが分る，ここでCは比例係数である。

へき開破壊じん性 $\left(J_{c}\right)$, 最初にセパレーションが発 生したときの丁積分 $\left(J_{\text {sep }}\right)$ および $J_{\text {inst }}$ の温度依存 性を Fig. 11 に示す. へき開破壊が発生したのは, $-100^{\circ} \mathrm{C}$ 以下の低温域に执いてのみである.さらに計 測されたへき開破壊の $J_{c}$ はすべて $5 \mathrm{kgf} / \mathrm{mm}$ 以下で ある．通常の溶接構造用鋼では，延性一ぜい性遷移温 度は $0 \sim-50^{\circ} \mathrm{C}$ と本供試材に比べてかなり高いものの そのときのへき開破壊の $J_{c}$ は 100～ $200 \mathrm{kgf} / \mathrm{mm}$ であ るのに対して, 本供試材のそれは約 $5 \mathrm{kgf} / \mathrm{mm}$ と極 めて小さな值を示している。これは，前報で詳細に考 察したごとく，き裂先端部にセパレーションが発生す れば，き裂先端部の塑性拘束が急激に緩和されて平面 ひずみ状態から平面応力状態に遷移するためである. すなわち，セパレーションの発生は平面ひずみ条件下 でのへき開破壞の発生を阻止する役目をはたしている と言光る.

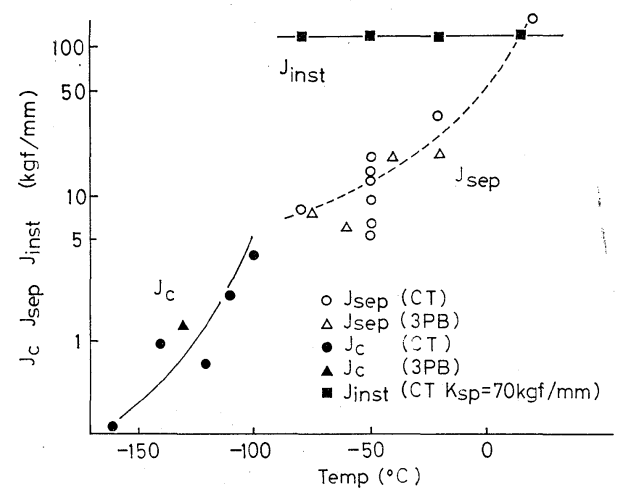

Fig. 11. Temperature dependence of $J_{\text {inst, }}$ $J_{\text {sep }}$ and $J_{c}$.

$J_{\text {sep }}$ は $-80^{\circ} \mathrm{C}$ 以上の温度域で計測され，かなり大き な温度依存性を示している。この $J_{\text {sep }}$ の温度依存性 は, セパレーションを形成するへき開破壊の破壊じん 性が温度の上昇につれて増大したことによるものであ る. 一方， $-100^{\circ} \mathrm{C}$ 以下に拈いては，セパレーション が発生する前に主へき開破壊が発生したために， J を評価することができなかった。

Fig. 11 の $J_{\text {inst }}$ は $a_{0} \fallingdotseq 26.5 \mathrm{~mm}, K_{\text {sp }}=70 \mathrm{kgf} / \mathrm{mm}$ のときの結果である. この $J_{\text {inst }}$ の温度依存性と比較 するために, セパレーション指数 (S.I.) の温度依存 性を Fig. 12 に示す。. ここで, S.I. とは破面で観察 されたある長さ以上のセパレーションの長さの総和を 破面の面積で除した值である. S. I. は室温から - 80 ${ }^{\circ} \mathrm{C}$ の温度範囲に打いて, 約 $0.03 / \mathrm{mm}$ から $0.5 / \mathrm{mm}$ までと相当変化しているにもかかわらず, $J_{\text {inst }}$ は匡と

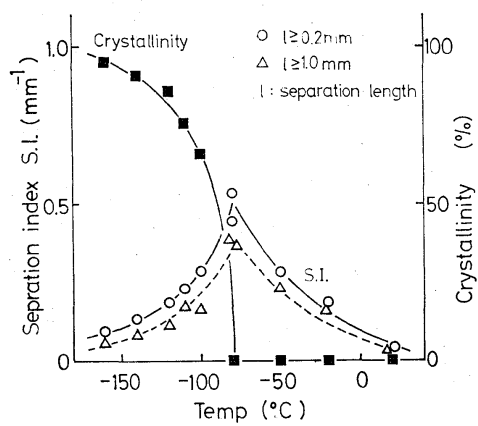

Fig. 12. Temperature dependence of separation index and crystallinity.

んど変化せず， $J_{\text {inst }} \fallingdotseq 110 \mathrm{kgf} / \mathrm{mm}$ と浪ぼ一定である. このことから, 本供試材においては, セパレーション の発生がかなり顕著な $-80^{\circ} \mathrm{C}$ 亿扣いても, 平面応力型 の低エネルギ引裂破壊は発生しなかったと言える。さ らにまた，室温を除いては， $J_{\text {inst }}$ が $J_{\text {sep }}$ らかなり 大きいことから, 最大荷重点以前に発生したセパレー ションは延性不安定破壊を誘起しなかったと言える.

Fig.11より，低コンプライアンスな荷重系すなわち ばねを介さないときの延性一ぜい性遷移温度は約 -90 ${ }^{\circ} \mathrm{C}$ である゙，高コンプライアンスな荷重系では -80 ${ }^{\circ} \mathrm{C} て ゙ も$ 延性破壊していることから，本供試材の延性一 や゙い性遷移温度はほとんどコンプライアンスの影響を 受けていないことが分る，一方，軟鋼材の場合には， 高コンプライアンスな荷重系で破壊じん性試験を実施 した場合，最大荷重点以後の速度効果により延性一ぜ い性遷移温度がかなり上昇することが知られている. この差はセパレーションの効果によるものであると考 えられる.すなわち，本供試材の場合，Fig. 3 や Fig. 12 等から， $-80^{\circ} \mathrm{C}$ での最大荷重点付近では相当のセパ レーションが発生していると言える.したがって，き 裂先端部は完全な平面応力状態にあるために，前報で 考察したような理由により, コンプライアンスによっ て動的効果が生じてもぜい性破壊しなかったものと考 壳らる。

\section{5 結 言}

二相域で制御圧延された50キロ高張力鋼を用いて， $-50^{\circ} \mathrm{C} て ゙ の J-R$ 曲線や延性不安定破壊特性の温度和 よびュンプライアンス依存性を検討した結果次のよう な結論が得られた。

（1）セパレーションの発生により，特異な荷重-変 位曲線を示す本供試材では，延性不安定破壊条件式(2) および(5)はそのままの形では適用できないが，平準化 した荷重一変位曲線からの $d P / d \delta$ を用いればほぼ妥当 な結果を得ることができた，乙かし，延性破壊荷重係 数 $T_{\text {app }}$ が約 300 以上の場合に拈ける式(2)の妥当性に ついてはさらに検討することが必要である. 
（2）延性不安定破壞発生時の $\mathrm{J}$ 積分（ $J_{\text {inst }}$ ）のばね 係数 $\left(K_{M}\right)$ 依存性は次式のように示すことができた.

$$
J_{\text {inst }}=J_{p \cdot \max }+C K_{M}
$$

（3）セパレーションの発生が顕著な低温域において も，薄板材に類似した低エネルギ引裂破壊は発生しな かった。

（4）最大荷重点以前に発生したセパレーションはぜ い性破壞や延性不安定破壊を誘起しないのみならず, 塑性拘束を低下させることにより，や゙い性破壞の発生 を防止する効果を示した。

(昭和58年6月24日 第 2 回破填力学シンポジウムにて講演)

\section{参 考 文 献}

1) 例咒ば, 安藤 柱, 松下久雄, 藤林伸平, 小倉信和, 材 料, 34, 379 (1985).

2）例光ば, 永元隆一, 日本鉄鋼協会, 第86,87回西山記念 技術講座，p. 225 (1984).
3）例えば, 杉江英司, 松岡雅典, 秋山俊弥, 三村 宏, 住 友芳夫，鉄と鋼，9，104（1983）.

4) ASTM Standard, E813-81.

5) 安藤 柱, 小倉信和, 小堀孝浩, 日本機械学会論文集, 46, 933 (1980).

6) P.C. Paris, H. Tada, A. Zahoor and H.A. Ernst, ASTM STP 668, 5 (1979).

7) H.A. Ernst, P. C. Paris and J. D. Landes, Sci. Paper, 80-ID3-JINTF-P3 (1980).

8) 安藤 柱, 堀野正也, 坂 真澄, 小倉信和, 日本機械学 会論文集，50，252（1984）.

9) 坂 真澄, 高橋秀明, 安藤, 柱, 阿部博之, 圧力技術, 22, 81 (1984).

10) 安藤 柱, 坂 真澄, 堀野正也, 古徳弘行, 日本機械学 会論文集 (印刷中).

11）金沢 武, 町田 進, 粟飯原周二, 日本造船学会論文集, 146, 474 (1979). 